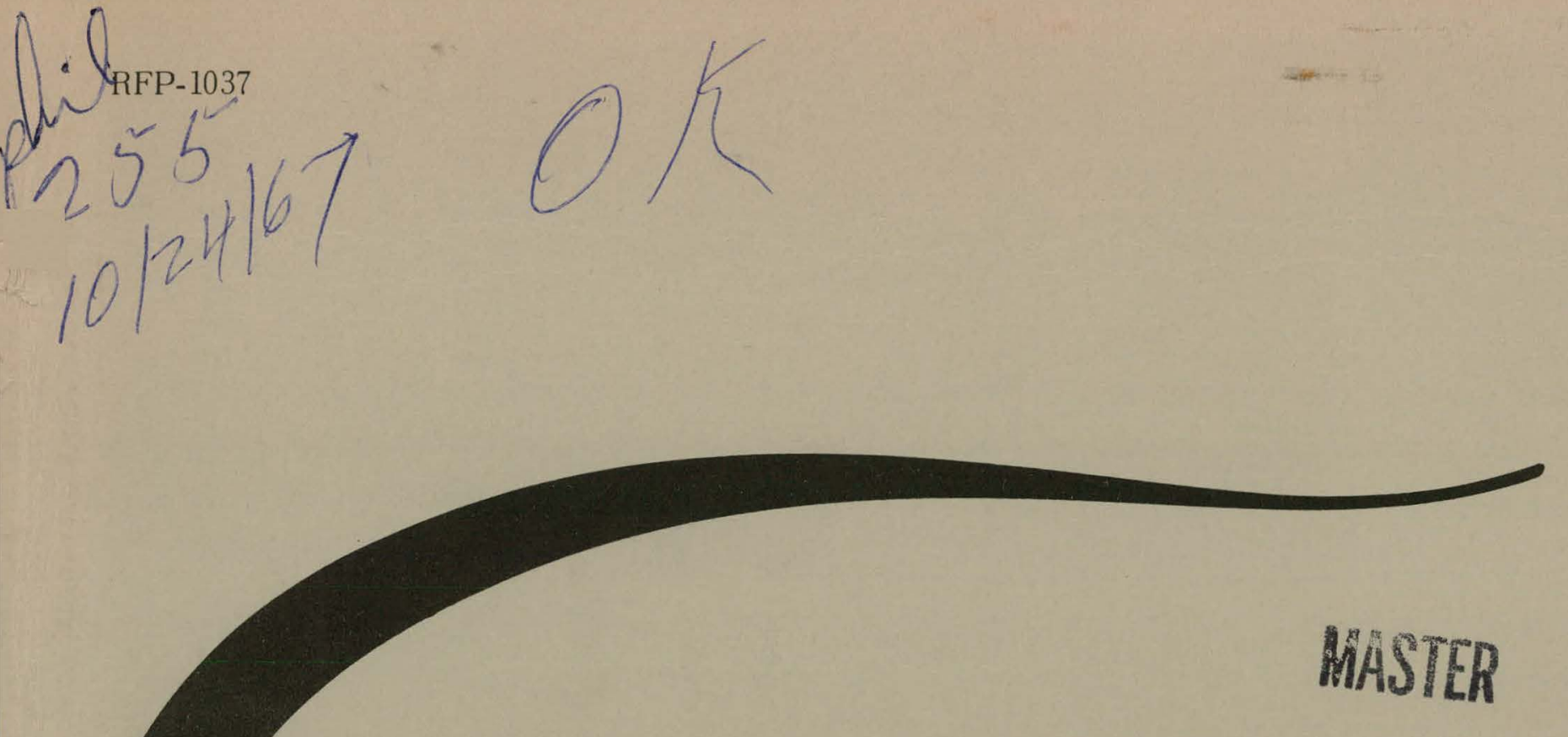

\title{
MASTER
}

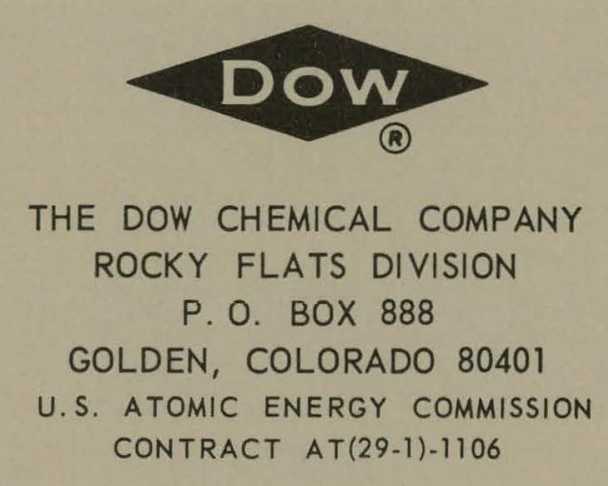

THE DOW CHEMICAL COMPANY

ROCKY FLATS DIVISION

P. O. BOX 888

GOLDEN, COLORADO 80401

U.S. ATOMIC ENERGY COMMISSION

CONTRACT AT(29-1)-1106

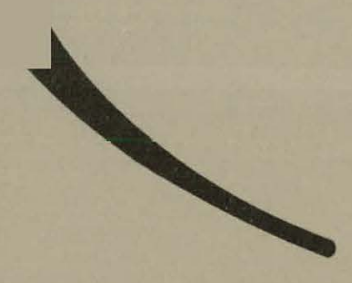

\section{THE REMOVAL OF SILICA FROM PLUTONIUM \\ PROCESSING ANION EXCHANGE RESIN \\ BY CAUSTIC WASH \\ BY CAUSTIC WASH}

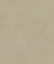

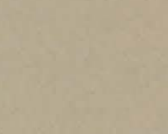

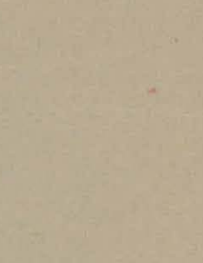




\section{DISCLAIMER}

This report was prepared as an account of work sponsored by an agency of the United States Government. Neither the United States Government nor any agency Thereof, nor any of their employees, makes any warranty, express or implied, or assumes any legal liability or responsibility for the accuracy, completeness, or usefulness of any information, apparatus, product, or process disclosed, or represents that its use would not infringe privately owned rights. Reference herein to any specific commercial product, process, or service by trade name, trademark, manufacturer, or otherwise does not necessarily constitute or imply its endorsement, recommendation, or favoring by the United States Government or any agency thereof. The views and opinions of authors expressed herein do not necessarily state or reflect those of the United States Government or any agency thereof. 


\section{DISCLAIMER}

Portions of this document may be illegible in electronic image products. Images are produced from the best available original document. 


\section{LEGAL NOTICE}

This report was prepared as an account of Government sponsored work. Neither the United States, nor the Commission, nor any person acting on behalf of the Commission:

A. Makes any warranty or representation, expressed or implied, with respect to the accuracy, completeness, or usefulness of the information contained in this report, or that the use of any information, apparatus, method, or process disclosed in this report may not infringe privately owned rights; or

B. Assumes any liabilities with respect to the use of, or for damages resulting from the use of any information, apparatus, method, or process disclosed in this report.

As used in the above, "person acting on behalf of the Commission" includes any employee or contractor of the Commission, or employee of such contractor, to the extent that such employee or contractor of the Commission, or employee of such contractor prepares, disseminates, or provides access to, any information pursuant to his employment or contract with the Commission, or his employment with such contractor.

Printed in the United States of America

Available from

Clearinghouse for Federal Scientific and Technical Information

National Burcau of standards, U. S. Department of Commerce

Springfield, Virginia 22151

Price: Printed Copy $\$ 3.00$; Microfiche $\$ 0.65$ 


\title{
THE REMOVAL OF SILICA FROM PLUTONIUM PROCESSING ANION EXCHANGE RESIN BY CAUSTIC WASH
}

\author{
Robert P. DeGrazio
}

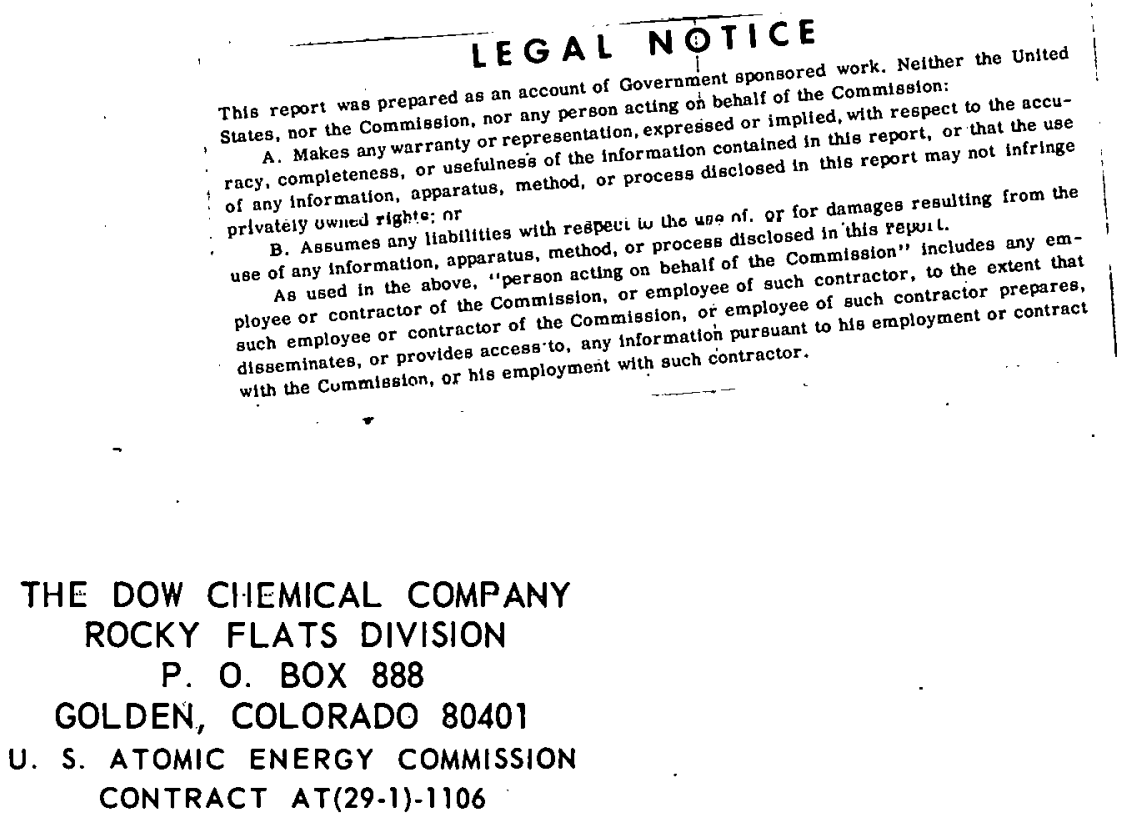




\section{ADDENDUM}

\section{The Removal of Silica from Plutonium Processing Anion Exchange Resin by Caustic Wash}

RFP-1037 Issued October 11, 1967

The following additions should be made as indicated:

Page 3: . Column 2, after 2nd paragraph add the following section:

Potential Hazards for Large Scale Operations:

In converting the resin to the nitrate form from the hydroxyl form on laboratory-șcale quantities (i.e., 158 grams resin), no increase in column temperature was detected. However, on large scale quantities (i.e., 4-inch-diameter columns) exothermic reactions could occur that could lead to column pressurization. ${ }^{y-10}$ Care should be taken to ensure complete nitration of the resin with $0.35 \mathrm{M} \mathrm{HNO}_{3}$ before reconditioning the resin with $7 \mathrm{M} \mathrm{HNO}_{3}$. The time required for complete nitration of the resin is based on the reaction of the particular type of anion exchange used. ${ }^{11}$

Page 3: Column 2, 3rd paragraph, include the following references:

8. W. J. Van Slyke, G. Jansen, Jr., and W. H. Swift, "Thermal Effects in Anion Exchange Rooin-Nitrio Aoid Syeteme," BNWL-114, August 1968.

9. H. T. Fullam, "Thermal Stability of Nitrate Form Anion Resins in a Vented Systcm," RL-SEP-826, December, 1965.

10. F. Helfferich, "Ion-Exchange," McGraw-Hill Book Company, Inc., New York, pp 488-489, 1962.

11. W. J. Van Slyke, "Final Report of Chemical Safety for Technetium-99 Recovery by Anion Exchange,"' BNWL-476, January, 1967. 


\title{
The Removal of Silica from Plutonium Processing Anion Exchange Resin by Caustic Wash
}

\author{
Robert P. DeGrazio
}

Abstract. DOWEX ${ }^{\circledR} 1$ anion exchange resin is used for the recovery and purification of plutonium from nitrate solutions. The resin is plugged with silica $\left(\mathrm{SiO}_{2}\right)$ preventing efficient processing of the plutonium. An experiment is described for the removal of silicon dioxide from the anion exchange resin.

\section{SUMMARY AND CONCLUSIONS}

Ion exchange is routinely used at Rocky Flats in the recovery and purification of plutonium. Silica $\left(\mathrm{SiO}_{2}\right)$ is present in certain plutonium recovery streams and is adsorbed rapidly on anion resin columns. Consequently, the resin columns are plugged, preventing efficient processing of the plutonium. Replacement of the resin is usually required every $l$ to 3 months.

Experiments were conducted on a laboratory scale to determine the feasibility and effectiveness of removing silica from anion exchange resins with a sodium hydroxide wash.

The results indicate that the procedure developed will effectively remove the silica and considerably increase the operational lifetime of the resin. The washing procedure is simple, safe and effective. Data show that approximately $99 \%$ of the adsorbed silica is removed. The concentration of plutonium in the caustic waste solution was below discard level, and therefore, did not require additional processing.

\section{INTRODUCTION}

Ion exchange is used at Rocky Flats in the recovery and purification of plutonium from nitrate solutions. Plutonium nitrate feed contains many impurities. Silica $\left(\mathrm{SiO}_{2}\right)$ is a major impurity in the feed and will rapidly plug columns containing DOWEX ${ }^{\circledR} 1$ aniun exchange resin, resulting in a decrease in feed throughput. Consequently, the resin must be replaced every 1 to 3 months. This condition is economically undesirable. The lifetime of the resin will be increased and column downtime decreased if silica can be removed from the resin bed without destroying the ion-exchange properties.
To prevent silica and other impurities from reaching the ion columns, the feed solutions are filtered using both gravity and pressure type filters. These filters are rated to remove particles greater than 3 microns. Silica, however, is found in process lines, process tanks, and the ion-exchange columns located downstream of the filters. This indicates that the filters are not stopping the silica impurity. Two reasons are suggested: (1) silica (at least in part) is in the sub-micron range, and (2) the silica is present in the feed solutions as a species other than $\mathrm{SiO}_{2}$. Investigations have shown that both hypotheses are valid. Infrared spectrophotometric analyses of plutonium feed solutions show the presence of the hydrofluosilicic acid ion $\left(\mathrm{SiF}_{0}=\right) .^{1}$ A microscopic analysis of the feed used in this study showed that silica is present in sub-micron. size particles.

During the acid leaching of plutonium-containing residues, the $\mathrm{SiF}_{6}=$ ion is probably converted to silicon tetrafluoride gas and hydrofluosilicic acid ${ }^{2}$ which is carried downstream and hydrolyzed elsewhere in the system, forming.colloidal, sub-micron silica particles. This form of silica probably accumulates and grows into large silica polymers on the ion-exchange resins and thus eventually plugs them.

Ion column experiments were performed on a laboratory scale to develop a procedure for the removal of silica from DOWEX 1 Resin. The procedure is similar to that used in the uranium ore processing industry, ${ }^{3}$ but was modified to plutonium production conditions.

Initial investigations were performed using synthetic feed solutions which contained no plutonium. This was to determine if degradation of the resin occurs when it is in contact with caustic solution under pressure. Other experiments were carried out with feed solutions containing plutonium.

\section{EXPERIMENTAL}

\section{Non-Plutonium Experiments}

Initially, the ion-column experiments were conducted with silica solutions which did not contain plutonium. 
The purpose of these experiments was to determine the effects of caustic on the resin when the resin was subjected to pressure.

A glass column having dimensions of 12 in. by 1 in. and a sintered glass frit at the base to contain the resin was used. The column contained DOWEX ${ }^{(B)}$ 1-X4, 50-80 mesh Resin in nitrate form except when treated with caustic solution. Pressurizing the system was accomplished by pumping the feed solution through a closed system. Pressures were regulated with a valving system and measured with pressure gages. The operating parameters used in this system are listed in Table I.

TABLE 1. Operating Parameters of Pressurized System.

Resin: 158 grams dry DOWEX(B) $1-\mathrm{X} 4,50-80$ mesh Resin, nitrate form

Temperature of Resin: $50^{\circ} \mathrm{C}$

lulet Pressure: 35 nisig

Flnw Rate: 100 liters/hour

Feed: $7 \underline{M} \mathrm{HNO}_{3}$ containing silica, aluminum nitrate, and calcium fluoride

\section{Silica Preparation}

Solutions of silica were prepared by dissolving sodium silicate in water and adjusting to $7 \underline{\mathrm{M}} \mathrm{HNO}_{3}$. At this acid molarity, silicon dioxide is precipitated. The total silica concentration, reported as $\mathrm{SiO}_{2}$, was determined by a modified emission spectroscopic method. ${ }^{4}$ The size of the silica particles was measured by diffraction microscopy and averaged between 1 and 5 microns.

\section{Plutonium Experiments}

Production plutonium feed solutions consisting of leached incinerator ash were used as a source for both silica and plutonium. One ash-feed assayed at $18 \mathrm{~g} / \mathrm{l}$ $\mathrm{Pu}$ per liter with a silica content of greater than 20 $\mathrm{mg} / \mathrm{l}$. In these experiments a nonpressurized system was used. The leed solution was circulated through a column containing DOWEX® 1 Resin using a tube pump as shown in Figure 1. The feed was pumped from a beaker to the top of the resin column at a rate of 12 liters/hour.

It was allowed to circulate through the resin column for 30 minutes and at the completion of th is loading cycle, the column effluent was analyzed for silica and plutonium. In another experiment, $400 \mathrm{ml}$ of plutonium

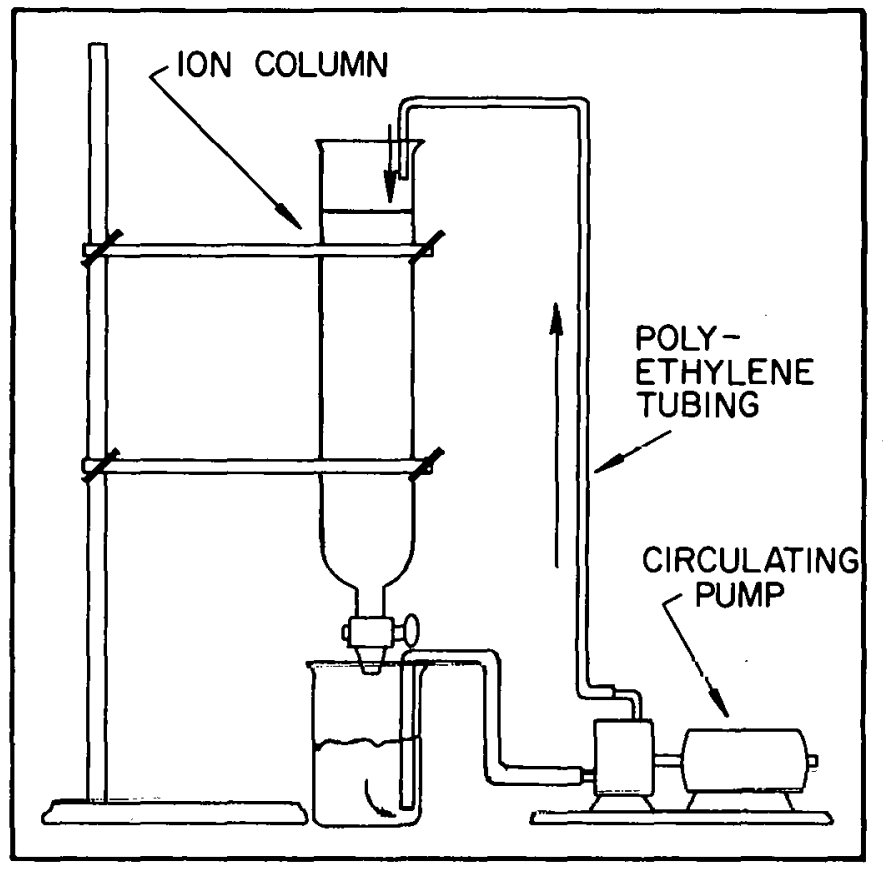

FIGURE 1. Ion-Exchange System.

feed, assaying at $18 \mathrm{~g} / \mathrm{l} \mathrm{Pu}$ in $7 \underline{\mathrm{M}} \mathrm{HNO}_{3}, 4 \mathrm{~g} / \mathrm{l}$ fluoride ion and $20 \mathrm{mg} / 1 \mathrm{SiO}_{2}$ were circulated through the resin bed for 30 minutes at a flow rate of 12 liters per hour. The feed was then allowed to remain in contact with the resin for 48 hours to promote silica growth (polymer formation) in the crosslinked polystyrene matrix. The resin was then washed with several column volumes of $7 \mathrm{M} \mathrm{HNO}_{3}$ until the $\mathrm{SiO}_{2}$ in the effluent was at background level. The resin was then analyzed for silica.

\section{Column Washing Procedure}

After loading the resin column with silica, it was washed with caustic. The stepwise caustic wash procedure used is shown in Table II, This procedure was used for both the nonplutonium and plutonium containing experiments.

\section{Analytical}

After washing the columns, samples were taken of the untreated resin, the washed resin, and the feed and wash solutions. Silica content was determined by emission spectroscopy. 
TABLE II. Procedure for Silica Removal from DOWEX 1 Anion Exchange Resin.

1. Elute the plutonium from the resin with $0.35 \mathrm{M} \mathrm{HNO}_{3}$.

2. Air sparge the resin to remove any solid material that may likely cement the resin together when the caustic solution is added.

3. Neutralize the acid in the column by passing $3 / 4$ column volume of $1 \mathrm{w} / \mathrm{o} \mathrm{NaOH}$ through the resin bed.

4. Pass $3 / 4$ column volume of $10 \mathrm{w} / 0 \mathrm{NaOH}$ through the bed to remove the silica contamination.

5. Neutralize the caustic by passing $3 / 4$ column volume of $0.35 \mathrm{M}$ $\mathrm{HNO}_{3}$ through the resin.

6. Recondition the resin to its nitrate form using $7 \mathrm{M} \mathrm{HNO}_{3}$.

7. Air sparge the column to remove any solids that may have been formed during acidification.

8. The column is now ready for the next plutonium loading cycle.

\section{RESULTS AND DISCUSSION}

Results from the non-plutonium, caustic wash experiments showed that: (1) no significant gassing occurred when converting the resin from an acidic to a basic form, (2) there was no temperature increase during this conversion, (3) there was no significant resin swelling when the resin was treated with caustic, and (4) there was no decrease in flow rate after repeating the caustic-acid cycle several times. However, degradation of the resin beads will occur if the temperature exceeds $50^{\circ} \mathrm{C} .{ }^{5}$ These results indicate that no degradation of the resin occurs during the washing treatment. The washed resin should be nearly as effective for plutonium purification as new, unused resin.

Solutions from the dissolution of plutonium-containing incinerator ash originally contained $18 \mathrm{~g} / \mathrm{l} \mathrm{Pu}$ and greater than $20 \mathrm{mg} / \mathrm{l}$ silica. The solution, after circulation through the resin, contained $0.04 \mathrm{mg} / \mathrm{l} \mathrm{SiO}$ and $0.31 \mathrm{mg} / 1 \mathrm{Pu}$ indicating that the resin had retained both silica and plutonium.

Microscopic examinations of plugged resin clearly show that the beads are covered with a white substance identified as amorphous silica, and that the spaces between the packed beads were also filled with this same substance. Other investigators have determined that silica will also aggregate and precipitate within the resin bead itself. ${ }^{6}$

The results of the caustic wash are shown in Table III.

TABLE III. Silica Removal by Caustic Wash.

\begin{tabular}{|c|c|c|c|}
\hline Exp. No. & $\begin{array}{l}\text { Total } \mathrm{SiO}_{2} \text { on } \\
\text { Resin (g) }\end{array}$ & $\begin{array}{l}\text { Total } \mathrm{SiO}_{2} \text { on Resin } \\
\text { after Caustic Wash ( } \mathrm{g})\end{array}$ & $\begin{array}{c}\mathrm{SiO}_{2} \\
\text { Removed (\%) }\end{array}$ \\
\hline 1 & 2.447 & 0.024 & 98 \\
\hline 2 & 0.895 & 0.009 & 99 \\
\hline 3 & 0.480 & 0.010 & 98 \\
\hline
\end{tabular}

After the caustic wash, the resin was analyzed for silica and found to be $0.01 \mathrm{mg} / \mathrm{g}$ resin. This amount was the same as the silica content in new resin. Microscopic examination showed that most of the amorphous silica had been removed. These results indicate that silica can be removed from the resin with the proposed wash treatment. Also, the plutonium concentrations in the caustic wash will be below the permissible discard level, and therefore, need not be reprocessed. The removal of approximately $98 \%$ of the silica will allow the previously plugged and nonadsorptive resin to be reused.

The method outlined for washing the resin columns and demonstrated with laboratory tests does not present any hazards. Others who have used similar washing treatments on anion resins also report no hazardous effects.

\section{ACKNOWLEDGMENTS}

The author is indebted to R. G. Auge for the nonplutonium experimental work; to L.'J. Meile for his generous information on metal production operations; and to F. J. Miner for his valuable suggestions and comments.

\section{REFERENCES}

1. A. J. Johnson. Rocky Flats Division, The Dow Chemical Company, Golden, Colorado. Work to be published.

2. C. A. Lorenzen. Development of a Continuous Dissolve for Plutonium Scrap. USAEC Report. ISO-SA-29. October 7, 1966.

3. J. W. Clegg and D. D. Foley. Uranium Ore Processing. Addison-Wesley Publishing Company, Reading, Massachusetts. 1958. Page 225.

4. R. A. Sandberg. Rocky Flats Division, The Dow Chemical Company, Golden, Colorado. Unpublished work.

5. Dowex:Ion Exchange.' The Dow Chemical Company, Midland, Michigan. 1964.

6. Ibid, Reference 1. Page 220.

7. R. M. Wheaton. Private communication. The Dow Chemical Company, Midland, Michigan. November 14, 1966. 